\title{
Reading, syntactic, and working memory skills of bilingual Portuguese-English Canadian children
}

\author{
HELENA A. DA FONTOURA' and LINDA S. SIEGEL ${ }^{2}$ \\ ${ }^{1}$ Universidade Federal Fluminense Niterói, Rio de Janeiro, Brasil; ${ }^{2}$ Ontario Institute for Studies \\ in Education, Canada
}

\begin{abstract}
The purpose of the study was to examine the nature of language, memory, and reading skills of bilingual students and to determine the relationship between reading problems in English and reading problems in Portuguese. The study assessed the reading, language, and memory skills of 37 bilingual Portuguese-Canadian children, aged 9-12 years. English was their main instructional language and Portuguese was the language spoken at home. All children attended a Heritage Language Program at school where they were taught to read and write Portuguese. The children were administered word and pseudoword reading, language, and working memory tasks in English and Portuguese. The majority of the children (67\%) showed at least average proficiency in both languages. The children who had low reading scores in English also had significantly lower scores on the Portuguese tasks. There was a significant relationship between the acquisition of word and pseudoword reading, working memory, and syntactic awareness skills in the two languages. The Portuguese-Canadian children who were normally achieving readers did not differ from a comparison group of monolingual English speaking normally achieving readers except that the bilingual children had significantly lower scores on the English syntactic awareness task. The bilingual reading disabled children had similar scores to the monolingual reading disabled children on word reading and working memory but lower scores on the syntactic awareness task. However, the bilingual reading disabled children had significantly higher scores than the monolingual English speaking reading disabled children on the English pseudoword reading test and the English spelling task, perhaps reflecting a positive transfer from the more regular grapheme phoneme conversion rules of Portuguese. In this case, bilingualism does not appear to have negative consequences for the development of reading skills. In both English and Portuguese, reading difficulties appear to be strongly related to deficits in phonological processing.
\end{abstract}

KEY WORDS: Bilingualism, Reading disability, Reading in Portuguese

\section{INTRODUCTION}

Bilingualism, or even multilingualism, is an aspect of educational reality for children in many areas of the world. As a result of immigration or ethnic background, many children grow up in the first few years of life learning to speak one language and then attend school in another language, the majority language of the country or province.

Canada has two official languages, English and French. In addition, multiculturalism is an official policy of Canada. In many communities across Canada, this policy means that children who come from homes in which neither English nor French is spoken receive most of their schooling in English 
or French (depending on the area of the country in which they live) but also receive some instruction in their 'heritage' or home language. Their linguistic environment is obviously different from that of children who come from homes in which one of the official languages of Canada is spoken and who receive reading instruction in that language. Little is known about the nature and extent of English (or French) and heritage language proficiency of these children.

One possibility is that there is a significant relationship between the skills in the two languages. This hypothesis, advanced by Cummins (1979), is the linguistic interdependence hypothesis. A corollary is the central deficit hypothesis, that children who have learning problems in their second language will also manifest similar difficulties in their first language. That is, children with deficient language and cognitive skills will experience problems regardless of the language.

There is the script dependent hypothesis in which reading problems are related to the orthographic features of the language and the predictability of the correspondence between graphemes and phonemes (e.g., Liberman, Shankweiler, Fischer \& Carter 1974; Lindgren, DeRenzi \& Richman 1985).

The available studies, of which there are very few, indicate a correlation between reading skills in two languages. In a study of groups of Berber- and Arabic-speaking children educated in Arabic in Morocco, Wagner, Spratt \& Ezzaki (1989) found that early differences in reading and language skills between the Berber- and Arabic-speaking children disappeared by the later grades. When French was introduced as a second or third language, French reading skills were related to reading skills in Arabic. In a study of children who were learning French as their third language (their main instructional language was English, their first [heritage] language was a language other than English because their parents were recent immigrants to Canada), Swain, Lapkin, Rowen \& Hart (1990) found that their proficiency in French was related to their proficiency in their heritage language. In addition, it did not matter whether their first language was a romance or a non-romance language.

For English-speaking children learning Hebrew as a second language, Geva \& Siegel (1991) found significant and substantial correlations between performance on word identification, pseudoword reading, working memory, and syntactic awareness tasks in English and Hebrew. In a study of bilingual Canadian Japanese children whose first language was Japanese and who received reading instruction primarily in English but some instruction in Japanese, Cummins, Swain, Nakajima, Handscombe, Green \& Tran (1984) found a correlation between skills in Japanese and in English. They found similar results with bilingual Canadian-Vietnamese children. In a study of college students who had difficulty learning a foreign language, Ganschow, Sparks, Javorsky, Pohlman \& Bishop-Marburg (1991) found that those students who had difficulty learning a foreign language also had difficulty 
with the syntactic and phonological processing and spelling of their first language.

The purpose of this study was to examine the nature of reading, phonological, syntactic, and working memory skills in a group of bilingual EnglishPortuguese speaking children in their two languages and to determine the relation between reading problems in English and Portuguese. These children received most of their schooling in English but received some instruction in Portuguese. All of these children came from homes in Canada in which Portuguese was spoken at home. In addition, they received instruction in speaking, writing, and reading Portuguese for one half hour per day in school.

English spelling is opaque and there are complex and often unpredictable relationships between graphemes and phonemes; Portuguese, although not perfectly regular, is a much more transparent language and has a much more predictable relation between graphemes and phonemes with few irregularities. The script dependent hypothesis would lead to the prediction that the irregularity of grapheme-phoneme conversion rules in English would create more reading problems than in Portuguese. The central deficit hypothesis would lead to the prediction that similar problems, if any, should be manifested in both languages because of a central processing deficit. Of course, these hypotheses are not mutually exclusive and it may be the case that performance in both languages is highly correlated but the language with the more shallow orthography might be easier to learn.

This study examined three processes that are significant in the development of reading skills in English (see Siegel 1993, for a detailed review). These processes are phonological processing, syntactic skills, and working memory. Phonological processing involves a variety of skills but in the context of the development of reading skills, the most significant is the association of sounds with letters, that is, the understanding of grapheme-phoneme conversion rules and the exceptions to these rules. This ability is the basis of decoding print, and although there are other routes to obtain meaning from print, the phonological route is clearly an important one and critical in the early development of reading skills (e.g., Stanovich 1988a, b). Syntactic awareness, also called grammatical sensitivity, refers to the explicit understanding of the syntax of the language. This ability appears to be critical for fluent and efficient reading of text which requires making predictions about the words that come next in the sequence. Working memory refers to the retention of information in short-term storage while processing incoming information and retrieving information from long-term storage. In the context of reading, working memory is relevant because the reader must decode and/or recognize words while remembering what has been read and retrieving information such as grapheme-phoneme conversion rules.

The purpose of this study was to examine the relationships between reading, language, and memory skills in English and Portuguese. 


\section{METHOD}

Subjects. The subjects were 37 students from a school in the Toronto area, a predominantly English speaking area of Canada. They were 9 to 12 years of age, 19 females and 18 males, in grades 4,5 and 6. All students were born in Canada from Portuguese native speaking parents who spoke little English. All the children in this group came from the lower socioeconomic level backgrounds. Typically, both parents worked in unskilled or semiskilled jobs. Most of the parents had very little education. The language spoken at home was Portuguese but all children had English as their first instructional language and attended Portuguese classes in school everyday for 20 to 30 minutes where they learned reading and writing skills in Portuguese. This program is called the Heritage Language Program, offered as an addition to the regular school curriculum by the Toronto School Board, and enrollment is voluntary. It is an opportunity for students to maintain and extend their knowledge of their language of heritage. Written consent, in Portuguese, for their children to participate in the study was obtained from all parents.

A comparison group of monolingual English speaking children were selected from a larger sample who had been administered the tasks in English (Siegel 1988; Siegel \& Ryan 1989a, b). These children were matched on chronological age with the Portuguese-English bilingual children. There were 57 normal readers (Wide Range Achievement Test, WRAT, Jastak \& Wilkinson 1984 , Reading percentile $\geq 30$ ) and 49 reading disabled children (WRAT Reading percentile $\leq 25$ ). The children came from schools in the same geographical area and were taught with the same methods. They were a more heterogeneous group in terms of socioeconomic status (SES) than the Portuguese-Canadian children and had a slightly higher SES level.

Tasks. The following tasks were administered:

Wide Range Achievement Test - Revised (WRAT-R, Jastak \& Wilkinson 1984): The reading and spelling subtests were used. The Reading test requires the child to read an increasingly difficult series of words. In the Spelling test, the child is required to write the correct spelling of an increasingly difficult series of words.

Woodcock Reading Mastery Test - (Woodcock 1973): Word Attack subtest. The child is required to read an increasingly difficult series of pseudowords according to the phonological system of English. Examples of the words used include bim, toaf, and cedge.

English Oral Cloze Task (Siegel \& Ryan 1988), where the children were instructed to fill in the missing word in each of 20 sentences orally presented. An example of a sentence is: 'Jane her sister ran up the hill'.

English Working Memory Task (developed by Siegel \& Ryan 1989a), based on the work developed by Daneman \& Carpenter (1980). The children were presented sentences orally with the final word missing and they had to supply 
it and repeat all the missing words from the set. There were three trials at each set size (2, 3, 4 and 5). Examples of sentences were: In summer it is very ; People go to see monkeys in a .; With dinner we sometimes eat bread and _. The child was required to repeat the three words he or she selected, in this case hot, zoo, butter, in the same order that they had been presented. To minimize word finding problems, the sentences were chosen so that the word was virtually predetermined.

Portuguese Word Reading: This task involved a list of 40 words shown to the children. They were asked to read them aloud. The words were selected from the Portuguese readers that the children used in school. The words are shown in Appendix 1.

Portuguese Pseudoword Reading: This task involved a list of 40 pseudowords and was designed to measure phonics skills, with words like sata, cosa, natoca, possible sound combinations in Portuguese but with no meaning. The pseudowords are shown in Appendix 1.

Portuguese Oral Cloze Task: This task was adapted from the English version used by Siegel \& Ryan (1988), and consisted of 20 incomplete sentences that were read aloud to the child, who was asked to supply the missing word orally. The sentences are shown in Appendix 1.

Portuguese Working Memory Task: This task was adapted from the English version used by Siegel \& Ryan (1989a), where the children were presented sentences orally, with the final word missing and had to supply it. The sentences were presented in sets of two, three, four and five missing words. At the end of each set they were asked to repeat all the missing words, in the same order that they had been given. If the child missed all items of a particular set size, the administration of the task was stopped.

Procedure. The children were seen individually in three sessions. In session 1 , they were administered the Portuguese Reading Word Task, the Portuguese Reading Pseudoword Task, the Portuguese Oral Cloze Task and the Portuguese Working Memory Task. An informal short interview was conducted in Portuguese to gather information about the birthplace of the child and the parents and the language most often spoken at home. Session 2 consisted of the English Oral Cloze Task and the English Working Memory Task and in session 3, the WRAT-R Spelling and Reading subtests and the Woodcock Word Attack subtest, were administered. An intelligence (IQ) test was not administered because of biases that are inherent in the use of IQ tests with minority group children (e.g., Gregory \& Lee 1986; Wolfram 1983).

In addition, Ribeiro (1980) has documented the difficulties of using standardized IQ tests such as the WISC-R and the Raven Progressive Matrices for low income Portuguese children in the US.-Ribeiro notes certain aspects of the culture that would lead to performance that would be different from the US reference group used in the norming procedure. 


\section{RESULTS}

\section{Correlations among tasks}

The intercorrelations among the tasks are shown in Table 1. As can be seen in Table 1, there were statistically significant correlations among English and Portuguese tasks measuring the same process, that is, English and Portuguese word reading 0.52, English and Portuguese pseudoword reading 0.64, English and Portuguese oral cloze 0.63, and English and Portuguese working memory 0.48 . There were also significant correlations among the word and pseudoword reading tasks within and between the two languages, suggesting the operation of similar processes in both languages on these tasks.

The oral cloze tasks were significantly correlated with the word and pseudoword reading in the same but not in the other language; working memory was correlated with only one of the reading tasks and only in Portuguese. The oral cloze and working memory were correlated within and between languages except for the case of English working memory and Portuguese oral cloze. Therefore, in most cases, there was a significant relation between English and Portuguese.

Table 1. Correlations among the tests

\begin{tabular}{|c|c|c|c|c|c|c|c|}
\hline & \multirow{2}{*}{$\begin{array}{l}\text { Word } \\
\text { reading } \\
\text { Portuguese }\end{array}$} & \multicolumn{2}{|c|}{$\begin{array}{l}\text { Pseudoword } \\
\text { reading }\end{array}$} & \multicolumn{2}{|c|}{ Oral cloze } & \multicolumn{2}{|c|}{ Working memor } \\
\hline & & Eng. & Port. & Eng. & Port. & Eng. & Port. \\
\hline \multicolumn{8}{|l|}{ Word reading } \\
\hline English & $0.52 * * *$ & $0.68 * * * *$ & $0.51^{* * *}$ & $0.35 *$ & 0.20 & 0.14 & 0.17 \\
\hline Portuguese & & $0.53 * * *$ & $0.63^{* * * *}$ & $0.30^{\mathrm{a}}$ & $0.33^{*}$ & 0.25 & $0.36 *$ \\
\hline \multicolumn{8}{|c|}{ Pseudoword reading } \\
\hline English & & & $0.64 * * * *$ & $0.35^{*}$ & 0.09 & 0.04 & 0.23 \\
\hline Portuguese & & & & 0.17 & $0.35 *$ & -0.01 & 0.17 \\
\hline \multicolumn{8}{|l|}{ Oral cloze } \\
\hline English & & & & & $0.63 * * *$ & $0.33 *$ & $0.48 * *$ \\
\hline Portuguese & & & & & & 0.24 & $0.33^{*}$ \\
\hline \multicolumn{8}{|c|}{ Working memory } \\
\hline English & & & & & & & $0.48 * * *$ \\
\hline \multicolumn{8}{|l|}{ Spelling } \\
\hline English & $0.60^{* * * *}$ & $0.68 * * * *$ & $0.46^{* *}$ & $0.37 *$ & 0.16 & $0.30^{\mathrm{a}}$ & $0.34 *$ \\
\hline
\end{tabular}




\section{Cognitive processes as a function of a reading disability}

The children were divided into two groups based on their score on the reading subtest of the WRAT-R. Normally achieving readers were defined as children whose scores were $\geqslant 30$ percentile; there were 24 of these children. Twelve children whose scores were $\leqslant 25$ percentile on the reading subtest of the WRAT-R were considered reading disabled; one child had a score at the 27th percentile and was not classified in either group. The mean scores on the Portuguese and English tasks are shown in Table 2. As can be seen in Table 2 , there were significant differences between the groups on all the Portuguese tasks except for the Oral Cloze and on all the English tasks except for the working memory. Therefore, the children who would be classified as reading disabled in English show significantly poor performance on most of these reading, spelling, language and memory tasks in both languages.

The group was arbitrarily divided into good and poor readers in Portuguese based on their scores on the Portuguese word reading. Children $(n=8)$ who had scores on the Portuguese reading test $\leqslant 23$ were labelled as poor readers; the children $(n=25)$ who had scores on the Portuguese reading test $\geqslant 26$ were labelled as good readers. Four children had intermediate scores and were not classified in either group. The comparisons are shown in Table 3. As can be seen in Table 3, the good readers had significantly higher scores on every task except Portuguese oral cloze and English working memory. The results are

Table 2. Mean scores on the English and Portuguese tasks as a function of group ${ }^{\mathrm{a}}$

\begin{tabular}{|c|c|c|}
\hline & $\begin{array}{l}\text { Normally } \\
\text { achieving } \\
\text { readers } \\
(n=24)\end{array}$ & $\begin{array}{l}\text { Reading } \\
\text { disabled } \\
(n=12)\end{array}$ \\
\hline \multicolumn{3}{|l|}{ Portuguese tasks ${ }^{\mathrm{a}}$} \\
\hline Reading words (40) & $31.3(5.1)$ & $23.1(6.8)^{* * *}$ \\
\hline Reading pseudowords (40) & $27.6(4.0)$ & $19.6(9.1)^{* * *}$ \\
\hline Oral cloze $(20)$ & $13.3(3.5)$ & $11.4(3.5)$ \\
\hline Working memory (12) & $5.1(1.7)$ & $3.7(1.5)^{*}$ \\
\hline \multicolumn{3}{|l|}{ English tasks ${ }^{c}$} \\
\hline WRAT reading (Words) ${ }^{\mathrm{b}}$ & $59.9(22.7)$ & $9.2(5.7)^{* * *}$ \\
\hline Woodcock (Pseudowords) ${ }^{\mathrm{b}}$ & $58.5(18.9)$ & $26.0(20.0)^{* * *}$ \\
\hline Oral cloze $(20)$ & $13.8(2.8)$ & $11.7(2.3)^{*}$ \\
\hline Working memory (12) & $6.0(2.1)$ & $4.9(1.8)$ \\
\hline WRAT spelling ${ }^{\mathrm{b}}$ & $55.8(22.0)$ & $19.4(21.1)^{* * *}$ \\
\hline
\end{tabular}

a Standard deviations are in parentheses.

b These scores are centiles; the remainder are raw scores.

c Maximum scores for each experimental task are in parentheses.

$* p<0.05 ; * * * p<0.001$ 
Table 3. Comparison of good and poor readers defined by their performance on Portuguese reading tasks ${ }^{k}$

\begin{tabular}{lcc}
\hline & $\begin{array}{l}\text { Poor readers } \\
(\mathrm{n}=8)\end{array}$ & $\begin{array}{l}\text { Good readers } \\
(\mathrm{n}=25)\end{array}$ \\
\hline $\begin{array}{l}\text { Portuguese tasks } \\
\text { Reading words }\end{array}$ & $18.1(3.9)$ & $32.7(3.3)^{* *}$ \\
$\quad$ Pseudoword reading & $17.8(10.6)$ & $27.9(3.5)^{* *}$ \\
$\quad$ Oral cloze & $10.9(3.2)$ & $13.2(3.9)$ \\
$\quad$ Working memory & $3.5(1.2)$ & $5.0(1.7)^{*}$ \\
English tasks & & \\
WRAT reading & $13.4(23.1)$ & $56.1(25.8)^{* *}$ \\
Woodcock word attack & $21.1(26.8)$ & $59.0(16.9)^{*}$ \\
$\quad$ Oral cloze & $11.1(2.2)$ & $13.6(2.9)^{*}$ \\
Working memory & $5.1(2.1)$ & $5.7(2.1)$ \\
WRAT spelling & $19.1(19.6)$ & $56.7(21.6)^{* *}$ \\
\hline
\end{tabular}

a Standard deviations are in parentheses.

b These scores are percentiles; the remainder are raw scores.

$* p<0.05 ; * * p<0.0001$

similar to those reported in Table 2. The most common mistakes were errors in stress of incorrect syllable and errors on vowels which were read with an English, as opposed to a Portuguese, pronunciation.

\section{Comparison with monolingual English normal and disabled readers}

The performance of the bilingual Portuguese-English children, both the normal and disabled readers, was compared with the performance of monolingual normal and disabled English speaking readers. These results are shown in Table 4. It is important to note that the majority of the children (67\%) had no difficulties in English although it was their second language. Their scores on the word and pseudoword reading, spelling and working memory tasks were equivalent to those of monolingual English speaking normal readers.

When the Portuguese-Canadian reading disabled children were compared with monolingual English-speaking reading disabled children, the scores of the two groups were not significantly different on the word reading and working memory task. However the Portuguese-English bilingual reading disabled children had significantly higher scores than the monolingual children on the WRAT spelling test and the Woodcock Word Attack test of the reading of pseudowords. The bilingual reading disabled children did have scores on the oral cloze task that were significantly lower than the monolingual children. 
Table 4. The mean scores of English-Canadian and Portuguese-Canadian normally achieving children and reading disabled children on reading, language, and memory tasks ${ }^{a}$

\begin{tabular}{lcc} 
& English-Canadian & Portuguese-Canadian \\
\hline Normally achieving & $(\mathrm{n}=57)$ & $(\mathrm{n}=24)$ \\
WRAT reading & $63.1(17.4)$ & $59.9(22.7)$ \\
Woodcock word attack $^{\mathrm{b}}$ & $55.0(22.5)$ & $58.5(18.9)$ \\
Working memory $_{\text {Oral cloze }}$ & $5.5(2.0)$ & $6.0(2.1)$ \\
WRAT spelling $^{*}$ & $16.4(2.4)$ & $13.8(2.8)^{* * *}$ \\
Reading disabled $_{\text {WRAT reading }}^{\mathrm{b}}$ & $45.3(26.2)$ & $55.8(22.0)$ \\
Woodcock word attack & $(\mathrm{n}=49)$ & $(\mathrm{n}=12)$ \\
Working memory & $9.4(6.4)$ & $9.2(5.7)$ \\
Oral cloze & $15.6(12.5)$ & $26.0(20.0)^{*}$ \\
WRAT spelling & $5.2(2.2)$ & $11.7(2.3)^{*}$ \\
\hline
\end{tabular}

a Standard deviations are in parentheses.

${ }^{b}$ Percentile scores; the remainder are raw scores.

$* p<0.05 ; * * p<0.01 ; * * * p<0.001$

\section{DISCUSSION}

The relationships among phonological, syntactic, and working memory skills are consistent with the findings of Geva \& Siegel (1991) and Siegel \& Ryan (1988). The strong relationship between pseudoword reading and word recognition across languages indicates that phonic skills are a significant component of reading of the particular alphabetic languages examined in this study. The high correlations between reading skills in English and Portuguese found in this study were similar to the correlations between reading in French and Arabic found by Wagner, Spratt \& Ezzaki (1989).

As English and Portuguese reading, language, and memory skills were highly correlated, these relationships are suggestive of individual difference variables as the significant determinants of reading skill, rather than difficulties being language dependent. Thus, the data from this study is consistent with the linguistic interdependence hypothesis. In general, the data reported in this paper are consistent with the hypothesis that bilingual children with reading problems in English are likely to show problems in their other language, in this case Portuguese. Similar problems were evident in both languages for the children who had difficulties. This close relationship between performance in both languages is suggestive of general language deficit in some children.

The results are suggestive of the importance of certain cognitive processes in the development of reading skills as outlined in Siegel (1993). Phonological processing skills, as measured by pseudoword reading, are highly correlated 
with word recognition skills in both English and Portuguese. Disabled readers in Portuguese show the same difficulties with phonological processing as do disabled readers in English. In both English and Portuguese, deficits in working memory and syntactic skills are also characteristic of individuals with a reading disability, although the degree of deficit is not as pronounced as with phonological processing.

The Portuguese working memory task, rather than the English working memory task, discriminated between the reading disabled and normal readers when English reading was being examined. This finding may indicate the significance of working memory in the first language acquired. It is interesting to note that the English Oral Cloze task, but not the Portuguese Oral Cloze, did differentiate between the bilingual reading disabled and normal readers. Therefore, syntactic skills seem to be more relevant to the language in which the reading is occurring while working memory may be a relation of individual difference variables.

The results of this study are analogous to those of Lambert \& Tucker (1972), Barik \& Swain (1975), and McDougall \& Bruck (1976) in their studies of French immersion in Canada. In the French Immersion programs, native English speaking children receive reading instruction in French. English instruction is started after several grades but these children catch up to monolingual English speaking children who receive instruction in English. There appeared to be some positive transfer from French to English in the case of reading skills. However, the French skills of these children lag behind monolingual French speaking children. For the bilingual children in the present study, if we consider Portuguese as their first language and English as their main instructional language, the results are similar to those with children in these French Immersion programs. For the children with normal reading skills, all of the reading and language skills that were measured were equivalent to monolingual English speaking children with the exception of the task that measured syntactic skills. In this case, bilingualism appears to have no adverse effects.

The Portuguese-English bilingual normal readers did have lower scores on the oral cloze task, a test of syntactic skills, than those of English speakers who were normal readers. Obviously, the Portuguese-English bilinguals have significantly less exposure to more complex English syntax as their parents speak to them in Portuguese although they have English speaking teachers, radio and television as models also. This exposure is not sufficient to bring them up to the level of the monolinguals, although it should be noted that the bilinguals did have adequate syntactic skills. Their errors did not show intrusions from Portuguese and resembled those of younger normal English speaking children (e.g., problems with subject verb agreement, irregular verbs) but not with word order or incorrect use of the article (which might be expected if there were intrusions from Portuguese syntax), providing some suggestive evidence for the limited exposure hypothesis. In a related study of Turkish-speaking children in the Netherlands, Verhoeven (1990) found that 
the Turkish-speaking children were not as proficient as the native Dutchspeaking children on word and pseudoword reading and sentence imitation tasks. However, many of the Turkish-speaking children displayed adequate proficiency.

The reading disabled Portuguese-English bilingual had significantly higher scores on the English pseudoword reading and word spelling tasks than a comparison group of monolingual English speaking reading disabled. This finding may reflect a positive transfer from the more predictable grapheme-phoneme conversion rules of Portuguese to the very opaque orthography of English. It is unlikely that socioeconomic factors were responsible because the socioeconomic level of the Portuguese bilinguals was lower than that of the English monolinguals. Rosier \& Farella (1976) report a finding that may be related. Students who learned to read in Navajo and English had higher reading scores than Navajo children who only learned to read in English, possibly because of the transparent nature of Navajo orthography. However, it should be noted that in the present study the effect occurred for reading disabled but not for the normally achieving bilinguals.

The results of this study show that bilingualism is clearly not an impediment to the development of reading, syntactic and memory skills. These results provide support for the Heritage Language Program in Toronto. Most of the children from Portuguese speaking homes who were being educated in English but receiving some instruction in Portuguese performed very well on the reading, memory, and language tasks in both English and Portuguese. Some of the Portuguese speaking children did show reading problems in English. However, they showed similar problems in Portuguese. Of course, it is impossible to determine how the reading and spoken language skills of these children compare with children in Brazil or Portugal who have received all of their instruction in Portuguese.

While this study was only conducted with one language, the results can be viewed as encouraging for the Heritage Language Program and for multiculturalism in general. Obviously, a great deal more research must be conducted before conclusive statements can be made. It is important to note that most of the bilingual Portuguese-Canadian children in this study showed levels of reading, and verbal working memory skills that were similar to those of monolingual English-speaking Canadian children. The bilingual children who did have problems had similar difficulties in English and Portuguese.

In a meta-analysis of studies of bilingual education, Willig concluded that 'participation in bilingual education programs consistently produced small to moderate differences favoring bilingual education for tests of reading, language skills, mathematics, and total achievement when the tests were in English, and for reading, language, mathematics, writing, social studies, listening comprehension, and attitudes toward school or self when tests were in other languages' (1985: 269). The results of this present study support this conclusion. 


\section{ACKNOWLEDGMENTS}

This research was supported by a grant from the Natural Sciences and Engineering Research Council of Canada to Linda S. Siegel. The authors wish to thank Mr. M. Lynch, principal of St. Veronica School, the children, parents and teachers for their generous cooperation, Margaret Lesperance and Sergio da Fontoura for their assistance and support, Keith Stanovich for his helpful comments on this study, Norman Himel for assistance with the data analysis, and to Letty Guirnela for secretarial assistance.

\section{APPENDIX}

\section{Portuguese Word Reading Task}

foca, roda, jarra, joelho, mala, queijo, está, harpa, cao, erva, peixe, garfo, aviao, égua, ovo, casa, índio, tambor, bolo, coelho, escova, onda, ilha, uvas, xícara, quatro, iman, zebra, esquimó, nuvem, sino, asa, dentes, águia, lata, pena, blusa, anel, vela, mesa

\section{Portuguese Pseudowords}

amos, mó, pota, binha, cosa, toa, voma, ártilo, sata, arol, errma, étua, eslata, incmo, onla, upa, dico, lica, tosa, sopi, natoca, gora, rele, fito, jarto, harma, zita, xamel, quala, mache, ponca, tanha, márfota, panhao, fissa, plátibo, martenda, bêndulo, latículo, estonátilo

\section{Portuguese Oral Cloze Task}

1. Os ___ comeram milho.

2. Fred cozinhou o pernil __ forno.

3. O ___ levou as vacas para o pasto.

4. Jane __ sua irma brincaram muito.

5. O dia estava claro, com um lindo céu

6. Maria _u um buraco com sua pá.

7. Joao ligou a luz para poder

8. Ele escreveu no quadro com um pedaço ___ giz.

9. A menina, __é alta, joga bem basquete.

10. O rapaz tinha olhos castanhos e um —_ agradável.

11. Por causa da chuva de ontem, as crianças __ dentro de casa.

12. Joana bateu na __ antes de entrar.

13. As crianças usam botas __ está a nevar.

14. Eu quero brincar com um brinquedo ___ seja divertido.

15. —_ é que John vai ao doutor hoje?

16. Frank queria andar __ no carro.

17. Quando entramos ___ sala de aula, devemos ficar quietos.

18. Papai _ para Tony uma carta.

19. Depois das férias, é defícil estudar

20. A mae de Paulo guardou os brinquedos os livros. 


\section{Portuguese Working Memory Task}

2a. (1) No jogo de futebol, chutamos a

(2) Em minhas suas maos, eu tenho dez

2b. (1) No outono, precisamos varrer as

(2) Quando estamos doentes, vamos ao

2c. (1) Um elefante é grande, um rato é

(2) A faca é usada para cortar

3a. (1) Corremos rápido, andamos

(2) Na biblioteca as pessoas lêem

(3) A mą̧a ê vermelha, a banana é

3b. (1) O sol brilha de dia, a lua brilha à

(2) Na primavera, o fazendeiro planta

(3) O bebe tinha cabelos loiros e olhos

3c. (1) No verao é muito

(2) As pessoas vao ver os macacos no

(3) No café da manha, comemos pao e

4a. (1) Por favor, passe o sal e a

(2) Quando nossa maos estao frias, usamos

(3) Quando vinha para a escola, botei no correio uma _-

(4) Depois de nadar, fiquei todo

4b. (1) A neve é branca, o carvao é

(2) Depois da escola, as crianças foram para

(3) O passarinho voa, o peixe

(4) O fazendeiro tirou leite da

4c. (1) No outono, as folhas caem das

(2) Tomamos sopa com uma

(3) Num dia quente, eu vou à piscina para

(4) Nós penteamos o nosso

5a. (1) Para a festa, a menina comprou urn lindo

(2) O algadao é macio, as pedras sao

(3) Após a comida, lavamos os

(4) No inverno, tiramos a neve do

(5) $O$ aviao sobe e depois ele

5b. (1) A tartaruga anda devagar, o coelho anda

(2) No aniversário comemos gelado e

(3) O pai é homem, a mae é

(4) Somar é fácil, multiplicar é

(5) A menina gosta de galopar no

5c. (1) Para cortar carne, nós usamos una

(2) De dia é claro, de noite ê

(3) Caes tềm quatro

(4) Na padaria compramos

(5) Um homern é grande, um bebe é

\section{REFERENCES}

Barik, H. C. \& Swain, M. (1975). Three-year evaluation of a large scale early grade French immersion program: The Ottawa study, Language Leaming $25: 1-30$.

Cummins, J. (1979). Linguistic interdependence and the educational development of bilingual children, Review of Educational Research 49: 222-251. 
Cummins, J., Swain, M., Nakajima, K., Handscombe, J., Green, D. \& Tran, C. (1984). Linguistic interdependence among Japanese and Vietnamese immigrant students. In: C. Rivera (ed.), Communicative competence approaches to language proficiency assessment: Research and application (pp. 60-81). England: Multilingual Matters Ltd.

Daneman, M. \& Carpenter, P. A. (1980). Individual differences in working memory and reading, Journal of Verbal Learning and Verbal Behavior 19: 450-466.

Ganschow, L., Sparks, R. L., Javorsky, J., Pohlman, J. \& Bishop-Marbury, A. (1991). Identifying native language difficulties among foreign language learners in college: A 'foreign' language learning disability?, Journal of Learning Disabilities 24: 530-541.

Geva, E. \& Siegel, L. S. (1991). The role of orthography and cognitive factors in the concurrent development of basic reading skills in bilingual children. Unpublished manuscript.

Gregory, S. \& Lee, S. (1986). Psychoeducational assessment of racial and ethnic minority groups: Professional implications, Journal of Counseling and Development 64: 635-637.

Jastak, S. \& Wilkinson, G. S. (1984). The Wide Range Achievement Test-Revised. Wilmington, DE: Jastak Associates.

Lambert, W. E. \& Tucker, G. R. (1972). Bilingual education of children. Rowley, MA: Newbury House.

Liberman, I. Y., Shankweiler, D., Fischer, F. W. \& Carter, B. (1974). Explicit syllable and phoneme segmentation in the young child, Journal of Experimental Child Psychology 18: 201-210.

Lindgren, S. D., De Renzi, E. \& Richman, L. C. (1985). Cross-national comparisons of developmental dyslexia in Italy and the United States, Child Development 56: 1404-1417.

McDougall, A. \& Bruck, M. (1976). English reading within the French immersion program: A comparison of the effects of the introduction of English reading at different grade levels, Language Learning 26: 37-43.

Ribeiro, J. L. (1980). Testing Portuguese immigrant children: Cultural patterns and group differences in responses to the WISC-R. In: D. P. Macedo (ed.), Issues in Portuguese bilingual education (pp. 89-112). Cambridge, MA: National Assessment and Dissemination Center for Bilingual Education.

Rosier, P. \& Farella, M. (1976). Bilingual education at Rock Point: Some early results, TESOL Quarterly 10: 379-388.

Siegel, L. S. (1988). Evidence that IQ scores are irrelevant to the definition and analysis of reading disability, Canadian Journal of Psychology 42: 201-215.

Siegel, L. S. (1993). The cognitive basis of dyslexia. In: R. Pasnak \& M. L. Howe (eds.), Emerging themes in cognitive development, Vol. 2: Competences (pp. 33-52). New York: Springer Verlag.

Siegel, L. S. \& Ryan, E. B. (1988). Development of grammatical sensitivity, phonological and short-term memory skills in normally achieving and learning disabled children, Developmental Psychology 24: 28-37.

Siegel, L. S. \& Ryan, E. B. (1989a). The development of working memory in normally achieving and subtypes of learning disabled children, Child Development 60: 973-980.

Siegel, L. S. \& Ryan, E. B. (1989b). Subtypes of developmental dyslexia: The influence of definitional variables, Reading and Writing: An Interdisciplinary Journal 1: 257-287.

Stanovich, K. E. (1988a). Explaining the differences between the dyslexic and garden variety poor reader: The phonological-core variance-difference model, Journal of Learning Disabilities 21: 590-604, 612 .

Stanovich, K. E. (1988b). The right and wrong places to look for the cognitive locus of reading disability, Annals of Dyslexia 38: 154-177.

Swain, M., Lapkin, S., Rowen, N. \& Hart, D. (1990). The role of mother tongue literacy in third language learning, Vox 4: 111-121.

Verhoeven, L. T. (1990). Acquisition of reading in a second language, Reading Research Quarterly 25: 90-114.

Wagner, D. A., Spratt, J. E. \& Ezzaki, A. (1989). Does learning to read in a second language 
always put the child at a disadvantage? Some counter evidence from Morocco, Applied Psycholinguistics 10: 31-48.

Willig, A. C. (1985). A meta-analysis of selected studies on the effectiveness of bilingual education, Review of Educational Research 55: 269-317.

Wolfram, W. (1983). Test interpretation and sociolinguistic differences, Topics in Language Disorders 3: 21-34. Aspen Systems Corporation.

Woodcock, R. W. (1973). Woodcock Reading Mastery Tests. Circle Pines, MN: American Guidance Services.

Address for correspondence: L. Siegel, Department of Instruction and Special Education, Ontario Institute for Studies in Education, 252 Bloor Street West, Toronto, Ontario, Canada M5S IV6 Phone: (416) 923 6641, Ext. 2652; Fax: (416) 9264725 